\title{
MAKING GENDER A SUBJECT OF DISCUSSION - A MISSION (IM) POSSIBLE IN THE 21TH CENTURY?! STUDENTS OF EDUCATIONAL STUDIES AS AN EXAMPLE WITHIN THE CONTEXT OF ACADEMIA
}

\author{
Sabine Klinger, Ines Findenig \\ University of Graz, Graz, Austria \\ E-mail: sabine.klinger@uni-graz.at, ines.findenig@uni-graz.at
}

\begin{abstract}
Higher education is supposed to create open-minded graduates within social topics. General assumptions about educational science transfer a quiet sensitive picture across in particular gender issues and the awareness of gender inequalities. In contrast to other disciplines, scientific debates about gender issues do have a long tradition, even if not always thematised as such. The curriculum of educational science offers a wide range of so called gender-seminars, where students can spend time on gender related topics and the awareness of gender equality. Women are overrepresented among educational students and regarding to a "new deal for young women" (McRobbie 2009), which may influence the way young woman and men think about the importance of gender-related topics, the question about the relevance of gender and gender issues for the discipline of educational studies often remains vague. According to this following research questions arose: how do students of educational science discuss gender issues, how does a de-articulation form gender issues, and how is rhetoric equality produced among university students of educational science. The data are based on a qualitative empirical survey composed of four group discussions carried out with 14 university students of educational studies from German speaking universities. The aim was to reconstruct and analyse both - an individual and collective - understanding or interpretations regarding gender issues. The findings of this study have revealed that the reflection of gender issues and talking about gender is somehow caught between gender equality, difference and usurpation. This takes into account the mechanisms and masking effects of neoliberal activation. Deliberations about how educational studies can handle these challenges should imply a gender-reflected understanding of learning and educational processes.
\end{abstract}

Key words: gender, de-examination of gender issues, higher education, university students

\section{Introduction}

Many people assume that educational studies represent a gender sensitive discipline and that pedagogues are aware of gender inequality. But qualitative research shows that among university students of educational studies first an awareness of gender equality and gender related topics as well as second a gender sensitive perspective cannot be taken for granted. Furthermore, gender-related topics are not the most popular and most prestigious subjects in the scientific field (cf. Schlüter \& Justen 2009). The French sociologist Pierre Bourdieu (2005) pointed out that gender issues and equality seem to require defence or justification. Some people think that there is no need anymore to talk about gender. In the discourse of seeing gender equality as a major achievement, modernity provides a strong normative background for ignoring and delegitimizing social inequalities based on gender in modern societies. In fact, it seems that the area of gender discrimination itself has changed. Angelika Wetterer, a German feminist soci- 
Sabine KLINGER, Ines FINDENIG. Making Gender a Subject of Discussion - A Mission (Im) Possible in the 21th Century?! Students of Educational Studies as an Example within the Context of Academia

PROBLEMS

OF EDUCATION

IN THE $21^{\text {st }}$ CENTURY Volume 60, 2014

102

ologist explains this phenomenon by describing it as a paradoxical situation. She has observed a big gap between how people act in regard to gender roles and equality in everyday life and what people really think and say about it. In a common sense, people think that gender equality, equal rights and equal partnerships are already a social norm although they do not live up to them. Wetterer (2003) refers to this as a "rhetorical modernisation", just like "gender scepticism" (Knapp 2008: 297) or "myth of equality" as Maria Funder (2005) calls it, can affect how university students speak and think about gender. There may be a difference between what they say and how they actually act.

Nowadays one sees a wide variety of so-called gender seminars in the field of higher education. Even if one works on the assumption that a study means a "conjunctive space of experience" (Bohnsack 2006: 280f.; Mannheim 1980), the question still remains as to whether this space builds the basis for talking about gender or modernisation processes (cf. Wetterer 2003), or rather covers it up. Angela McRobbie (2009), a British feminist cultural theorist has pointed out that today young women are confronted with "new gender discussions" (p. 9) and that they have been offered a "new deal for young women" (p. 87) which may influence the way young woman and men think about the importance of gender-related topics. Thus, what looks like a result of personal choices and individual decision-making is, in fact, affected by the academic environment and social patterns. In other words, there is a certain disciplinary normative understanding of science, which prevents a subject like gender to be integrated. But on the other hand, social relations also exercise a certain power over the acting subjects. This is why we think that it is also necessary to focus on the everyday lives and practices of people. For us, it was important to ask the question as to how university students evaluate gender issues and how their ways of thinking about gender-related topics are influenced or, even more basic, how these attitudes were developed in the first place. This is why two different analytical levels are used: the academic and the everyday lives of university students. These considerations are influenced by the ideas of Pierre Bourdieu (2005). He argued that social structures and individuals would interrelate. Both are constitutively linked together. But before a short overview of Bourdieu's habitus concept is given an explanation of how we conceptualise academia as well as educational studies as a part of it all will be shown.

Following Joan Acker's (1999) approach, it can be assumed that academia and its structure is not, in fact, gender neutral. The same holds true for social structures and social processes. The American feminist sociologist states that an organisation, or any other analytical unit, is gendered. That means that advantages and disadvantages, exploitation and control, action and emotion, meaning and identity, are structured by the distinction between male and female, masculine and feminine. Gender is not an additional sub-category of on-going processes, which are generally referred to as "gender neutral". Rather, it is an integral part of those processes, which cannot be properly understood without an analysis of gender itself (Acker 1990). Gender is implied in the fundamental, on-going processes of creating and conceptualising social structures. It is obviously a constitutive element in private life relationships, but implicitly it helps to frame the underlying relations of other institutions, including complex organisations like academia. Gender is a constitutive element of organisational logic and structure.

The intention was not to analyse academia as a gendered organisation, but to use this concept of academia to investigate its influence on university students in their way of thinking about gender. In other words, there is a certain disciplinary norm in the understanding of science that shapes and creates opinions of university students on topics such as gender. Acker (1997) has said that gendered processes are not only concrete activities, i.e. what people do or say, but also how they think about these activities. Now this is what is really interesting: both the actions of university students and their way of thinking about, and evaluating gender related topics, is influenced by gendered processes and reflects academic structures.

The habitus-field concept of Pierre Bourdieu here serves as a theoretical background to 
seize how mechanisms and function modes of the scientific field affect individual ways of interpretation and collective thinking about gender relations and gender-related topics. Bourdieu has

PROBLEMS

OF EDUCATION

IN THE $21^{\text {st }}$ CENTURY

Volume 60, 2014

argued that a set of fields will inform and limit practices from a meta perspective. First of all, the distinction between habitus and field is a tenuous one. A habitus is formed over time but is also formative itself. It is a site for the reproduction of the belief in the reality of a given social field, a belief by which that field is sustained. But the habitus also generates dispositions which are credited with making the social subject act in relative conformity with the ostensibly objective demands of the field (Butler 1999). How does the habitus work? The habitus does not take effect in the generation of dispositions alone; the field acts out its demands as well. It is only on the condition that a feeling for the game is developed, a feeling for how to operate within the established norms of the social field that the habitus is built up. The habitus presupposes the field as the condition of its own possibility and existence (cf. Butler 1999) and, in this research, questions of which conditions are constituted by Educational Studies (as one example for the academic field) to think about gender, or to form an opinion appeared.

It is for this reason that in the following transformations of gender debates within educational studies will be discussed. This is one aspect of the university students' background. Another one is the social gender discourses. Therefore, one has to differ between theoretical scientific perspectives within (educational) women's and gender studies and social gender discourses.

\section{Current State of Research: Transformations of Gender Debates in Educational Studies}

Regarding the transformations of gender debates, it is important to distinguish between (a) theoretical scientific perspectives within (educational) women's and gender studies and (b) social gender discourses.

(a) Theoretical gender debates

By now, a wide range of gender theories and research approaches exist. Gender - as the main object of research - is discussed in the field of tension between gender equality and gender difference, or even up to the point of undoing this category. In the early 1970s, approaches of socialisation built the programmatic political frame to discuss critical women's issues. During the 1980s, this approach differentiated between empirical and theoretical aspects, leading to the concept of gender-related socialisation (cf. Dausien 2006: 22f.). This model distinguishes between female and male in order to be aimed at a decreased level of polarisation between the genders. As a result, the latter point has been subject to criticism; different valuation of gender tends to intensify and reproduce instead of nullify (cf. Breitenbach/Hagemann-White 1994: 256). Bettina Dausien, a German educational researcher, summarised the criticism on the concept of gendered socialisation in three points: (1) the methodological problem of re-naturalisation and re-ification, (2) the theoretical construction and too strong focusing on gender differences, and (3) the assumption of a clearly stable gender identity. From these critical points arose the existing paradigm shift (valid until now) towards constructivist and de-constructivist approaches. Both try, in different ways, to take corrective measures regarding the idea of the gendered socialization paradigm (cf. Dausien 2006: 25). Although there is this change, it seems necessary to pick up the socialisation-related thoughts again within this research to illustrate their potential for gender and social critical research.

While the socialization paradigm focuses on demonstrating that gender is more a social category than just biological fate, nowadays terms like intersectionality, interdependence and queer studies aim at different concerns. Although there is a wide variety of discussions about gender differences within gender studies, a sense of mutuality can be found thinking of Simone 
Sabine KLINGER, Ines FINDENIG. Making Gender a Subject of Discussion - A Mission (Im) Possible in the 21th Century?! Students of Educational Studies as an Example within the Context of Academia

LATION

OF EDUCATION

IN THE $21^{\text {st }}$ CENTURY

Volume 60, 2014

de Beauvoir's assumption: "one is not born a woman, but becomes (...)" (cf. Villa 2008: 201). With this in mind, the concept of gender has to be seen as a category of social differences and as a way of social-cultural being and existence (cf. Maierhofer 1995: 108). In this way, the recognition of various sexualities and gender identities is associated; and this, in its turn, allows for a continuum of different ways of (co-)existence, beyond femininity and masculinity. At the same time, gender is recognised and understood as a result of social allocation of importance; gender binarity is already structured as a patriarchal hierarchy. Gender identities and sexualities are socially constructed and a constitutive structural element and reproduction of the dominating heterosexual discourse and norms. Although, the research does not focus on individuals identifying as male and female, it is necessary to understand gender identity not as being something stable, but as something fluid. Therefore, the phrase ways of existing and being refers to an understanding of (gender) difference as positive and not hierarchical, allowing the possibility that various genders and gender identities can and should exist (cf. ib.: 172).

Moreover, within gender studies, questions about modernisation and the relevance of gender relations are increasingly being discussed. Angelika Wetterer, for example, has noted that the contemporary state of research is characterised by contradictions, disruptions and nonsimultaneity (cf. 2003: 288), which will be discussed later on. She has also identified a rhetorical modernisation for the present time, which appears to be some orientation on gender equality in discourses and language but not within the everyday life practise.

(b) New gender debates and discourses within the society

In consideration of a common denominator about the "idea of equality" (Koppetsch/ Burkart 1999: 193), i.e. looking at gender and gender relations as social inequalities, seems outdated (cf. Rendtorff 2005: 34f.). Despite the fact of the much celebrated two-sex relaxation in media (man vs. woman), it appears that everyday life practice is still strongly characterised by heteronormative samples. Biological interpretations of relationship and family models, gender roles and sexual orientations are still booming. They build the basis for (re) structuring processes of gender differences as well as for hierarchical gender systems (cf. Klinger/Kagerbauer 2013: 129).

According to what was said above, Angelika Wetterer referred to simultaneity of modernisation processes, the change of gender differences and their reformulation in structural persistence. She described how society handles the coexistence of equality and inequality as well as the gap between convictions, and how individuals act. She summarised this process by calling it a rhetorical modernisation, appearing in discourse and language but not within the everyday life practise (cf. Wetterer 2006: 12). Individuals tend to dissolve this contradiction through de-examination of inequality, which does, however, not solve the problem. Thus, gender hierarchy is excluded and invisible in the speakable repertoires (cf. ib. 2003: 290). This means the reaction about the discrepancy between convictions and acting is cloaked in secrecy about still consisting inequalities (cf. ib.: 286). Referring to Cornelia Koppetsch and Günter Burkart (1999), Wetterer described the mechanisms as being reverted to this process, as a "logic of discourse" (ib.: 298). Here the term inequality can be understood as a "result of a free and aware decision" (ib.) for which individuals are responsible; so structural problems get personalised and individualised. This paradoxical situation means that, within the logic of practice, social inequalities continue to exist and, that based on the logic of discourse, rhetoric equality dominates. 


\section{Methodology of Research}

Based on the thesis that de-examination about gender related questions is clasp a rhetoric modernisation and a new deal for young women; the research concentrates on the assumption that all university students are members of this space of experience and all make the same or similar experiences. These familiarities constitute a binding element between individuals and forms a collective layering of experiences (cf. Schäffer 2012: 142), and can be taken as the basis for talking about gender.

The presented data is based on four group discussions (one gender heterogeneous and one gender homogeneous groups per university) with 14 educational studies students ( 2 male and 12 female; 7 bachelor and 7 master students; between their 2nd and 13th semesters, the youngest person was 21 and the oldest was 45 years. The questioned students volunteered for the group discussions and they did not know that the main topic would be about gender-related issues. Thus the students did not think out themselves' as specially gender affine. The composition of the groups followed the principle of "real groups" because they normally have the same base of experience (Przyborski/Wohlrab-Sahr 2009: 113). The smallest group consisted of two students and at the biggest five students took part. The discussions were named wood, fire, water and a metal (cf. Klinger 2014: 157ff.) and were analysed using the documental method by Ralf Bohnsack (ib. 2008: 134ff.). There exists a variety of publications about group discussions and the document analysis method (cf. for example Bohnsack 2008, Przyborski/Wohlrab-Sahr 2009), thus not further explanations will be given. The transcription is orientated on the rules of "talk in qualitative social research" (TiQ) (ib.: 166f; Bohnsack 2008: 235).

The group discussions were held at two German speaking universities, which both include (trans-) disciplinary dimensions of structured implemented gender aspects in their education. Participating university students there have the possibility (within and outside their major subject) to deal with gender and gender relations. At both universities, centres for gender research and feministic science offer classes (cf. Klinger 2013: 101f.). Following the results of the research will be shown based on four statements from the held group discussions. The common understanding and individual development of attitudes in regard to gender related topics are to be reconstructed and analysed. The focus of this analysis lies on the question of how individuals interpret and understand their experience within the academic field, and how these interpretations are significant for their actions and their way of thinking. Through analysis, it is possible to see that university students act in order to comply with rhetoric modernisation; thus they represent a social conjunctive space of experience.

\section{Results of Research}

(A) How and in which ways student discuss about gender issues

Results of the research show that among students gender related topics seemed to be less compatible and discussable then other topics that concern social inequality. For example, individual contributions concerning gender from participants of the group discussion remained as not reflected comments and went without apparent notice of the others. For example, in the group metal (5 bachelor students, 4 female, 1 male, between 21 and 45 years) one student criticised the androcentric contents of a class and the lack of comprehensive gender-sensitive contents within the curriculum. This critical point remained an individual point of orientation within the group; none of the other participants shared her critique but told her that this is not what she is supposed to learn during her studies. A similar example was recognised in another group (water) consisting of three female master students between the age of 23 and 26. One 
Sabine KLINGER, Ines FINDENIG. Making Gender a Subject of Discussion - A Mission (Im) Possible in the 21th Century?! Students of Educational Studies as an Example within the Context of Academia

OF EDUCATION

IN THE $21^{\text {st }}$ CENTURY

Volume 60, 2014

106

participant spoke about her interest in analysing gender issues and how she first developed this interest. She described it by saying "I attended this class coincidentally, (...) it was on gender and education, (...) then I found it kind of interesting (...)". There were no responses and no shared interest recognised. Within the group discussions gender topics seemed less compatible and discussable. Only after the discussion moderator introduced the topic again and thus established it, the groups started to talk about gender and unfolded a discussion addressing a topic such as:

- Positive and negative experiences with gender lectures

- Gender issues are dominated by woman issues

- Opinions and discussions which are perceived as too extreme (gender sensitive language, women only groups, feminism movement now a days)

- Educational studies as a female dominated field

- Homosexuality of male students

- Female pedagogues are not as well respected as their male colleagues, especially in their working fields.

- Appreciation and depreciation of femininity

- Questioning the necessity of gender-sensitive language

- Questioning the discrimination of woman

- Importance and possibilities of gender issues for social work and social pedagogy

- Unimportance and limitations of gender studies within educational studies

- Relevance of discussing gender binary and gender roles

- Reproduced gender stereotypes and gender binarity

- Gender as an obsolete category when it comes to social inequality

The main result of the research is that university students do not have an established culture of discussing gender related topics, nor do they have a collective stock of knowledge about gender issues acquired through their studies. It is striking that gender hierarchy and feminist approaches are not discussed and individualisation of success and failure seems to be the new credo.

\section{De-articulation forms of gender issues}

The group discussion of six bachelor students (wood) was driven by the idea that women have already achieved the aim of gender equality. It became clear in this context that university students do not have an established form and culture of discussion, nor do they have a collective stock of knowledge about gender issues through their studies. It seems that aspects of the new deal for young women rather conceal the study than allow for a conjunctive space of experience. The following excerpt illustrates McRobbie's thesis that achievements of feminism are recognized and are included in our everyday life and yet, at the same time, the highlighting of gender issues is refused because equality appears to have been obtained (cf. McRobbie 2012: $32)$.

(Group: wood)

Luan: $\quad$ Sometimes I think, I mean we are all in a privileged situation, that for us some female beings have achieved something, (...) and I think in our everyday life at university, I don't have the feeling to have to justify something, about women and men, I mean; and female students and male students, or so. (...)1 
Luan then highlighted the orientation that women today live in a "privileged situation" and that they have "achieved something". At this point Luan recognized the achievements of early generations of women; but it is conjecturable that she did not see the necessity to insist on gender differences because today at least at the university everything seems better and egalitarian.

The following statement about gender-inclusive language 2 and the discussion about it's relevance is exemplary for all group discussions. The quoted discussion (wood) was held with five bachelor students. The discussion about gender sensitive language is especially important because in general German speakers and writers traditionally use masculine terms, nouns and pronouns in situations where the gender of their subject(s) is unclear or variable, or when a group to which they are referring contains members of both sexes. But since a few years there is an ongoing discussion about the relationship between our language use and our social reality. People argue that women or other sex are erased from language that makes it easier to maintain gender inequality. But the results of the research show, the questioned students do not share this point of view.

(Group wood, begin line 1273)

Loris: So, the "Schüler" [male pupil], and then hyphen below, and then "innen" [last syllable for the German grammatical ending for female pupils]

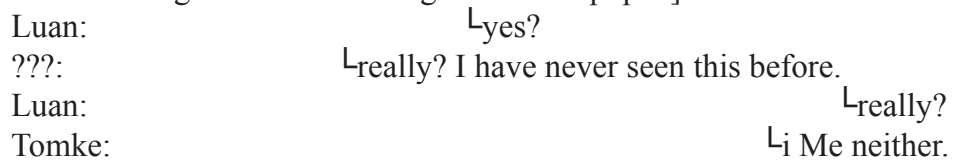

Loris: $\quad$ Because, i heard (laughing)

Luan: $\quad \mathrm{L}_{\text {why? }}$

Loris: it is because, because then all are included, even the ones who don't know

Luan :

they are female or male

Loris : $\quad \mathrm{L}_{\text {yes, that's right. }}$

Luan : $\quad$ Lall right.

Loris: that they are also included (laughing).

Luan: $\quad L_{\text {the }}$ third gender

Robyn: oh my god, that's so punctilious.

Loris: (laughing)

Tomke: from gender management to diversity management (2)

(murmur and deep exhalation through the group)

Luan: then I think it is exhausting.

(laughter)

Robyn: I think is very exhausting in education science to discuss such minor things for nothing.

Loris brought in new aspects, namely that there existed more than two genders and two gender identities and that they could easily be included in the language. This stock knowledge had not been given to all participants, and it was not the collective orientation of the group and therefore not visible in the sense of the reactions described by Robyn, Tomke and Luan. According to Robyn, "oh my god, that's so punctilious" lies an implicit rejection. The term "that" could refer to a way of writing (hyphen below) and to mention the possibility of a third gender. Further rejection could be interpreted by audible murmur and a deep exhalation through the group. Luan summarized her statement by saying, "I think it is exhausting"and thus distances herself also thereof. Final Robyn showed her rejection by said, it "is very exhausting in education science to discuss such minor things for nothing." In the context of gender issues raising 
Sabine KLINGER, Ines FINDENIG. Making Gender a Subject of Discussion - A Mission (Im) Possible in the 21th Century?! Students of Educational Studies as an Example within the Context of Academia

OF EDUC

PROBLEMS

IN THE $21^{\text {st }}$ CENTURY

Volume 60, 2014

108

awareness through language seems to be unnecessary and for nothing. Unlike other categories which result in social inequality.

In the following quote two students from the same group (wood) talk again about the importance of using a sensitive language but this time towards handicapped people. In this regard Robyn clarified the importance to reflect and discuss the different meaning of the terms and its implications.

(Group wood, begin line 1325)

Robyn: Yes, no, but I have to say, nevertheless I liked the class, because there are lots of things which have to be discussed, because there is something there.

Loris:

L think with all these terms it's a matter of terms in general, that humans get designations, I think the criticism about this is, well, that's the reason why I think it is important to talk about it. Because a handicapped person is a human being and the handicap should not be in the foreground, therefore I think the discussion about terms and a sensitive language is important here.

Tomke: $\quad$ yeah, that's right. Also about attentiveness, raising awareness.

In the spirit of this example, Robyn elaborated that she liked the class "nevertheless", saying, "... because there are a lot of things, which have to be discussed". Here she distinguished between topics which had to be discussed, i.e. important topics and unimportant ones (although she did not explicitly say so). These relevant issues, thus differed from unimportant ones "because there is something there" and is therefore not only theoretical but also practical. Loris took up the question about relevance of issues and asked for a discussion of "terms in general". For her, the debate about terms was necessary, because "it is important to talk about it". As an example she used the term for a handicapped person, saying that the discussion about terms was important. Tomke validated this through expanding the discussion about "creating" awareness. In this way she clarified how important it is to discuss terms because often complexity and ambiguity of terms would get lost in the linguistic usage, or would remain unconsidered.

In a comparison of the excerpts of gender-inclusive language and in relation to other categories of difference, there seemed to be an ability to reflect. Furthermore the comparison between the two examples about gender-inclusive language and the relevance of discussion about terms illustrates the difference within (critical) analyses regarding categories of inequality. Characteristic of all groups seemed the tendency to represent 'moderate' opinions and to dissociate from and reject 'extreme' positions and over-focussing on gender issues. They think of gender-including language, feminism and highlighting of gender as main category of inequality as one-sided and discussed as "too extreme" within the groups.

The next section shows how university students link up the 'equal issue' and the representation of women and men - in educational studies the numbers of female students is much higher - with the idea that gender equality und feminist's aims have indeed come true.

\section{(A) Orientation on rhetoric equality}

The group fire consisted of two bachelor students and out of this discussion a "kind of rhetoric equality" (McRobbie 2009: 18) was able to be drawn. It became obvious that the participants had its discussion against the background of the assumption that gender equality has been achieved and therefore (feministic) interventions and criticism on (patriarchal) dominance relationships was no longer necessary. 
(Group fire, beginning line 529)

Alex: I also assume that for us, well, in our age nobody thinks this is important; there may be some people, but they are a minority who are willing to push this. (...) we know why it is like this, but principally we also know that it lies way behind us, I mean, the topic. Do we really need to discuss it and bring it up again? (...) it is like something banal where you could think: it is getting annoying. That's my impression right now.

Nikita: $\quad$ Yes, I always have the feeling that the ones who insist on it, principally ... I mean like a point@emancipation is@ that (also)women have to be explicitly mentioned,... unconditionally the female form of the word, but like I said, for me it doesn’t play any role at all, $(\ldots)$

Alex: $\quad$ I would feel the same if I would read in a paper about male or female therapists or pedagogue [which, in German, is indicated by a gender specific grammatical ending] that I know from my everyday experience, there are female and male ones, (...). [and] in the end it's open to all who they choose.

Nikita: $\quad$ Yes, I agree.

Alex decided for herself that the value of the orientation of gender-inclusive language was not important and would limit her perspective to a certain age group or generation. As far as age was concerned, she indicated implicitly that it depended on the generation. The debate about gender-inclusive writing and speech was said to be found in the same frame of importance like today's equality and early discrimination ("lies behind us") issues. The participants counted themselves among a 'younger' generation and they failed to see the importance of a gender-inclusive language by saying only minorities would push the issue. For them, gender equality and emancipation seemed (at least within the labour market) as achieved, and they seemed to think a pursuing demand for it was "banal" and "it getting annoying". The university students made clear that they were already emancipated and felt they were having equal rights. By feeling addressed in the generic masculine, they felt validated in terms of emancipation and gender equality. They verbally asserted gender equality. Through calling the generic masculine 'right and normal' they emphasised, though, that gender-inclusive language was a formal requirement which had to be met in an academic manner.

The logic of this excerpt can be summarized like this: For Alex and Nikita, emancipation and gender equality is already achieved, and so this chapter seemed closed for the younger generation. They identified the reached equality within the opportunity for women to work "in the end everyone can make their choice". According to that, all options would then be open for men and women alike, which would lead to an individualisation of success and failure. Problems, discrimination and obstructive social structures seem nothing to speak of. All group discussions distinguish between early situations and nowadays. In doing so, the university students attempted to clarify that today women feel emancipated and treated as equals. Self-determination, autonomy and gender equality are part and parcel of young women's everyday life knowledge. Unlike in earlier times, they emphasized, today for women and men all possibilities are open. They make gender and gender issues a subject of discussion, but through highlighting the "early' times, a lack of necessity is implicated, and in conclusion this leads to a de-examination.

\section{Conclusions}

On the basis of the empirical analysis of the four group discussions (wood, fire, water and metal) it has become obvious that an educational study cannot be sure to find that the awareness of gender as a professional and scientific issue can be taken for granted. Moreover, the findings have revealed that the relevance of gender (issues) is increasingly becoming disconnected from a critical policy analysis and tends to overlook a gender inequality. The research shows that gender issues and gender related topics are very difficult to talk about because all questions 
Sabine KLINGER, Ines FINDENIG. Making Gender a Subject of Discussion - A Mission (Im) Possible in the 21th Century?! Students of Educational Studies as an Example within the Context of Academia

PROBLEMS

OF EDUCATION

IN THE $21^{\text {st }}$ CENTURY Volume 60, 2014

110

about gender hierarchies, feminist approaches and systematic discrimination are excluded. If university students talk about gender they speak about (a rhetorical) gender equality. Special about the field of educational students is the high proportion of women. In all group discussions this serves as an argument that a talk about gender issues and gender inequality is not necessary. Students assume that because of the high number of female students 3 , there is no need to discuss gender based discrimination. But this does not mean that individuals did not experience discrimination. The idea that there is no discrimination against women due to the static overrepresentation of women leads the impression that the relevance of the social category gender no longer needed in educational studies. Moreover, gender is extensively practiced as a stable bipolar concept, and much of its understanding remains not reflected. Unreflexive practising is thus consequential in professional work.

Deliberations about how educational studies can handle these challenges should imply a gender-reflected understanding of learning and educational processes. As part of the study, it seems useful to benefit from the critical and empowering potential of pedagogical processes. Therefore, it appears to be necessary to use enhanced gender-reflected teaching concepts for strengthening the university students' behaviour and their relationship to social and pedagogical contexts. New Concepts for classes are important, which analyse and work on gender issues without missing to consider the triad consisting of theoretical, pedagogical-practical and critical (biographical self-) reflection. On the one hand, considering new neoliberal discourses and structures and, on the other hand, thinking of transforming social conditions, it seems expedient to pursue the question about de-examination of gender and gender hierarchies to expand the previous thoughts with a perspective about socialisation. This means the high importance of highlighting the socialisation function of social reference groups and their common language as a main aspect of socialisation practice. Focusing social reference groups allow looking closer into the de-examination of gender within participation forms, as well as recognition, discrimination and power relations. With this in mind in times of neoliberal reductions, new debates and negotiations about socialisation of gender de-examination have to be considered.

\section{References}

Beauvoir, S. (2003). Das Andere Geschlecht. Sitte und Sexus der Frau (The other gender. Women custom and sexuality). 3rd Edition, Reinbek bei Hamburg: Rowohlt Verlag.

Bilden, H., \& Dausien, B. (2006) (Eds.). Sozialisation und Geschlecht. Theoretische und methodologische Aspekte (Socialisation and gender. Theoretical and methodological aspects). Opladen: Verlag Barbara Budrich. pp. 163-178.

Bohnsack, R. (2008). Rekonstruktive Sozialforschung. Eine Einführung in qualitative Methoden (Reconstructive social research. An introduction into qualitative methods). 7th Edition, Opladen \& Farmington Hills.

Bourdieu, P. (2005). Die männliche Herrschaft (The male domination). Frankfurt: Suhrkamp. [Original Edition: (1998). La domination masculine. Paris: Editions du Seuil].

Breitenbach, E., \& Hagemann-White, C. (1994). Von der Sozialisation zur Erziehung. Der Umgang mit geschlechterdifferenter Subjektivität in der feministischen Forschung (From socialisation to education. Coping with different gender subjectivity within feministic research) . In K. Beutler (Ed.), Jahrbuch für Pädagogik 1994. Geschlechterverhältnisse und die Pädagogik (Yearbook of pedagogy 1994. Gender relations and pedagogy). (pp. 249-264). Frankfurt am Main: Peter Lang Verlag.

Butler, J. (1999). Performativity's Social Magic. In R. Shusterman (Ed.), Bourdieu. A Critical Reader. Blackwell.

Dausien, B. (2006). Geschlechterverhältnisse und ihre Subjekte. Zum Diskurs um Sozialisation und Geschlecht (gender relations and its subjects. To the discourse about socialisation and gender). In H. Bilden \& Dausien, B. (Ed.), Sozialisation und Geschlecht. Theoretische und methodologische Perspektiven (Socialisation and gender. Theoretical and methodological perspectives) (pp. 1744). Opladen \& Flamington Hills: Verlag Barbara Budrich. 
Degele, N. (2008). Einführung Gender/Queer Studies (Introduction gender/queer studies). München: Wilhelm Fink Verlag.

Faulstich-Wieland, H., \& Horstkemper, M. (2012). Geschlechterverhältnisse (Gender relations). In W. Thole, H. Faulstich-Wieland, K. Horn, H. Weishaupt, \& I. Züchner (Eds.), Datenreport Erziehungswissenschaft 2012 (report of data 2012) (pp. 194-211). Opladen \& Farmington Hills: Verlag Barbara Budrich.

Götsch, M. (2012). n' Kerl mit sechzehn Jahren, der noch nie 'nem Weib an die Wäsche gegangen ist, gibt's ja eigentlich kaum noch. Sozialisation heteronormativen Wissens (there is no 16 year old boy who didn't hit on a girl. Socialisation of heteronormative knowledge). Unpublished doctoral dissertation at Albert-Ludwigs-University Freiburg in Breisgau.

Grundmann, M. (2006). Sozialisation. Skizze einer allgemeinen Theorie (Socialisation. Sketch of a general theory). Konstanz: UVK-Verlagsgesellschaft (UTB).

Jacobs, E. (1851). The Voice of Harriet Taylor Mill.

Klinger, S. (2014). (De-)Thematisierung von ,Geschlecht‘. Habituelle (Re-)Konstruktionen bei Studierenden der Erziehungs- und Bildungswissenschaften ((de-)examination of ,gender‘. Habitual (re-) constructions within educational university students . Opladen, Berlin \& Toronto: Budrich UniPress.

Klinger, S., \& Kagerbauer, L. (2013). (De-)Thematisierungen und neoliberale Verdeckungen am Beispiel feministischer Mädchen_arbeit - ein Zwischenruf ((De-)examination and neoliberal cover ups on the example of feministic girls_work - an interjection). Gender - Feministische Perspektiven auf Ökonomie und Geschlechterordnung (Gender - feministic perspectives about economics and genderorders), 5 (2), 129-138.

Knapp, G. (2008). Achsen der Differenz. Aspekte und Perspektiven feministischer Grundlagenkritik (Axes of difference. Aspects and perspectives of feministic fundamental criticism). In S. M. Wilz (Ed.), Geschlechterdifferenzen - Geschlechterdifferenzierungen. Ein Überblick über gesellschaftliche Entwicklungen und theoretische Positionen (Gender differences - gender differentiation. An overview about social developments and theoretical positions) (pp. 291-322). Wiesbaden: VS Verlag.

Koppetsch, C., \& Burkart, G. (1999). Die Illusion der Emanzipation. Zur Wirksamkeit latenter Geschlechtsnormen im Milieuvergleich (The illusion of emancipation. About effectiveness of latent gender norms in milieu comparison). Konstanz: UVK Verlag.

Maihofer, A. (1995). Geschlecht als Existenzweise. Macht, Moral, Recht und Geschlechterdifferenz (Gender as a way of existence. Power, moral, la wand gender difference). Frankfurt am Main: Ulrike Helmer Verlag.

Maihofer, A. (2004). Geschlecht als soziale Konstruktion - eine Zwischenbetrachtung (Gender as a social construct - an in between observation). In K. Pühl, T. Paulitz, D. Marx, \& U. Helduser (Eds.). Under construction? Konstruktivistische Perspektiven in feministischer Theorie und Forschungspraxis (Under construction? Constructive perspectives in feministic theory and research practice) (pp. 33-43). Frankfurt/Main and New York: Campus Verlag.

McRobbie, A. (2009). The Aftermath of Feminism: Gender, Culture and Social Change. Sage Publications.

Przyborski, A., \& Wohlrab-Sahr, M. (2009). Qualitative Sozialforschung. Ein Arbeitsbuch (Qualitative social research. A working book). 2nd Edition, München: Oldenbourg Verlag.

Maurer, S. (2006). Gouvernementalität, von unten her' denken. Soziale Arbeit und soziale Bewegungen als (kollektive) Akteure ,beweglicher Ordnungen' (Governmentality thinking, from below 'Social work and social movements as (collective) actors of, moveable orders'). In S. Maurer \& S. Weber (Eds.): Gouvernementalität und Erziehungswissenschaft: Wissen - Macht - Transformation (Governmentality and educational science: knowledge - power - transformation) (pp. 233-252). Wiesbaden: VS Verlag für Sozialwissenschaften.

Martin, P. Y. (2006). Practicing Gender at Work: Further Thoughts on Reflexivity. Gender, Work and Organization, 13 (3), 254-276.

Rendtorff, B. (2005). Strukturprobleme der Frauen- und Geschlechterforschung in der Erziehungswissenschaft (Problems of female- and gender research sturctures within educational science). In R. Casale, B. Rendtorff, S. Andresen, V. Moser, \& A. Prengel (Eds.), Jahrbuch Frauen- und Geschlechterforschung. Geschlechterforschung in der Kritik (Yearbook female- and gender research. Gender research criticism) (pp. 19-40). Opladen und Bloomfield Hills: Verlag Barbara Budrich. 
Sabine KLINGER, Ines FINDENIG. Making Gender a Subject of Discussion - A Mission (Im) Possible in the 21th Century?! Students of Educational Studies as an Example within the Context of Academia

PROBLEMS

OF EDUCATION

IN THE $21^{\text {st }}$ CENTURY

Volume 60, 2014

Schäffer, B. (2012). Erziehungswissenschaftliche Medienforschung - Medienpraxiskulturen im Generationenvergleich (Educational research and media science - media practice cultures within the comparison of generations). In F. Ackermann, T. Ley, C. Machold, \& M. Schrödter (Eds.): Qualitatives Forschen in der Erziehungswissenschaft (Qualitative research within education science) (pp. 135-156). Wiesbaden: Springer VS.

Schlüter, A., \& Justen, N. (2009). Pädagogische Biographiearbeit mit Studierenden zur Förderung von Genderkompetenz (pedagogical biography work with students to encourage gender competences). In M. Auferkorte, et al. (Eds.), Gender als Indikator für gute Lehre. Erkenntnisse, Konzepte und Ideen für die Hochschule (Gender as an indicator for good teaching. Knowledge, concepts and ideas for academia) (pp- 169-179). Opladen \& Farmington Hills.

Walgenbach, K. (2012). Intersektionalität als Analyseperspektive heterogener Stadträume (intersectionality and perspectives of analyses within heterogenous urban space). In E. Scambor, \& F. Zimmer (Eds.), Die intersektionelle Stadt. Geschlechterforschung und Medien an den Achsen der Ungleichheit (The intersectional city. Gender research and media within the inequality axis) (pp. 81-92). Bielefeld: Transcript Verlag.

Wetterer, A. (2002). Arbeitsteilung und Geschlechterkonstruktion. „Gender at Work” in theoretischer und historischer Perspektive (Distribution of tasks and construction of gender "Gender at work' in theoretical and historical perspective) . Konstanz: Universitätsverlag Konstanz.

Wetterer, A. (2003). Rhetorische Modernisierung: Das Verschwinden der Ungleichheit aus dem zeitgenössischen Differenzwissen (Rhetorical modernisation. The disappearing of inequalities during contemporary difference knowledge). In G. Knapp, \& A. Wetterer (Eds.), Achsen der Differenz. Gesellschaftstheorie und feministische Kritik II (Axis of difference. Social theory and feministic criticism II) (pp. 286-319). Münster: Verlag westfälisches Dampfboot.

\section{(Endnotes)}

1 The citations from the group discussions have been translated from German to English with an attempt to keep the content the same as much as possible.

2 In German, the generic masculine/exclusively male language is/can be used to express all human beings "without distinguishing them by a characteristic so little worthy of being made the main distinction as that of sex. This is more than a defect in language; tending greatly to prolong the almost universal habit, of thinking and speaking of one-half the human species as the whole" (cf. Jacobs 1851: 216f.). Gender-inclusive language, gender-inclusive language, or gender neutrality is a form of linguistic prescriptivism that aims to eliminate (or neutralize) reference to gender in terms that describe people. In this section the university students discuss about the necessity of gender-sensitive language.

3 In Germany for example in $201176 \%$ of pedagogy students are female (cf. FaulstichWieland/Horstkemper 2012:194)

\section{Advised by Vincentas Lamanauskas, SMC "Scientia Educologica”, Lithuania}

Received: May 09, 2014

Accepted: June 20, 2014 
Sabine KLINGER, Ines FINDENIG. Making Gender a Subject of Discussion - A Mission (Im) Possible in the 21th Century?! Students of Educational Studies as an Example within the Context of Academia

PROBLEMS

OF EDUCATION

IN THE $21^{\text {st }}$ CENTURY

Volume 60, 2014

113

Sabine Klinger

Mag. ${ }^{a}$ Dr. ${ }^{\text {in }}$ MA, Postdoc, University of Graz, Merangasse 70/ll, 8010 Graz Austria.

E-mail: sabine.klinger@uni-graz.at

Website: http://erziehungs-bildungswissenschaft.uni-graz.at/de/institut/arbeitsbereich-sozialpaedagogik/

Ines Findenig

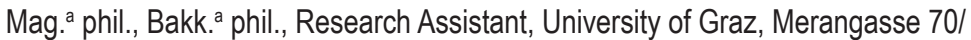

II, 8010 Graz, Austria.

E-mail: ines.findenig@uni-graz.at

Website: http://erziehungs-bildungswissenschaft.uni-graz.at/de/institut/arbeitsbereich-sozialpaedagogik/ 